\title{
Labor Demand and Export-Oriented Industrialization of Bangladesh
}

\author{
Taharima Sultana* \\ Department of Economics, Noakhali Science and Technology University, Noakhali, Bangladesh. \\ *Correspondence: taharimahashi52@gmail.com
}

\begin{abstract}
This thesis based on the findings of a study on labor demand and export-oriented industrialization in Bangladesh at the time of 1992-93 to 2016-17. For this persistence, secondary data from different sources (BBS, WDI, EPB, BER, WB, BB, etc) for the time duration 1992-2017 has been composed and analyzed through econometric tools. The test approves that the disturbance terms are normally distributed. To detect that the data suffer from multicollinearity, heteroscedasticity, and autocorrelation problem, the diagnostic test has been adopted. From the diagnostic test, it is detected that while the data free from heteroscedasticity and autocorrelation problems, however, the data suffer from severe multicollinearity problem. The multicollinearity problem is removed using remedial measures. The Unit root test has been detected to test the stationarity of the composed data. Among different unit root test, ADF-test is adopted. The test displays that the data are stationary at the first difference level for export-oriented industrialization and the second difference level for labor demand. The Johansen co-integration test is adapted to test whether the data are cointegrated at any level. The test results approve that six variables are cointegrated on labor demand and one variable cointegrated on export-oriented industrialization. The Granger causality test under VAR (Vector Autoregressive Regression) framework displays the variable has a unidirectional causal relationship with the dependent variable where all independent variables lead, and the dependent variable follows. However, these relationships have found a statistically significant positive impact of labor demand and export-oriented industrialization in Bangladesh. Thus, there is a dynamic relationship between domestic labor demand, export, and economic progress in Bangladesh.
\end{abstract}

Keywords: Employment, Labor, Export, RMG, Exchange rate, Industrialization, Growth rate, and Bangladesh.

\section{INTRODUCTION:}

As a sufficient labor country, the scene of the entire economy of Bangladesh depends on the structures of the labor market. In economics, the labor demand of an employer is the number of labor-hours that the employer is willing to hire founded on the different exogenic variable quantity it is faced- lined with, such like the wage rate, the unit charge of capital, the market determined retailing price of its output, etc (Van, 2009; Adnan, 2018). In fact, the demand for employment is not appropriate enough to generate the job opportunity for the current unemployed as well as underemployed workers. Hence, the economy faces an excess supply of labor. However, this sector is playing a noteworthy part in advance Bangladesh to the current position. In the world of globalization, economic development is highly correlated with the use of human capital (Khan and Ullah, 2017; Islam and Hossain, 2014). It stimulates economic growth through increasing the level of workers' efficiency and productivity (Jajri and Ismail, 2010; Mitchell, 2008)

The key objectives of the study are to find out Labor Demand and Export-Oriented Industrialization of Bangladesh as follows: To present the situation of labor demand and export-oriented industrialization in Bangladesh; to investigate econometrically the impact on labor demand of many exogenous variables 
in our economy; to assess the impact of exportoriented industrialization on the economic growth of Bangladesh; to examine the average of existing of labor based on them wages by the study (Michael, 2017). Labor demand and export-oriented industryalization as one of the major components of economics activities play a central role in providing nutrition, employment, and foreign exchange earnings in the economy of Bangladesh (Ahmad and Khan, 2007; Krainara, 2007).

Bangladesh is well recognized across the globe for its stunning success in the ground of readymade garment industries (BGMEA, 2013). It comprises about $80 \%$ of the entire export of Bangladesh. It has stayed able to make employment opportunities for millions, ease poverty, accelerate industrialization, appeal foreign direct investment, activate business, and generate an encouraging image of Bangladesh abroad (Rasiah and Nazeer, 2016). A good number of examines have been completed on numerous problems going from gender discrimination, the influence of globalization in the garment trade of Bangladesh (Tran and Norlund, 2015).

This paper may justify the importance of labor demand and export-oriented industrialization in Bangladesh. This also helps to analyze which one is more effective on the labor demand and what steps should take to make those significant for the development of the export industrialization (Getahum, 2018; WDI, 2020).

RESULTS:

Table 1: Descriptive test of Log of Total Employment (Source: Test Designed by EViews $10^{+}$Student Version Lite).

\begin{tabular}{|c|c|c|c|c|c|c|c|}
\hline & LNEMP & WR & LNIPC & LNGDP & LNFDI & AR & UEMP \\
\hline Mean & 16.80552 & 35.72992 & 25.06219 & 14.90528 & 2.658707 & 64.63759 & 3.531385 \\
\hline Median & 16.82721 & 35.57850 & 24.93155 & 15.43663 & 2.658472 & 63.75378 & 3.574000 \\
\hline Maximum & 17.36284 & 39.71100 & 26.24362 & 17.07540 & 3.048562 & 80.96719 & 5.000000 \\
\hline Minimum & 16.28880 & 31.89800 & 24.17986 & 10.20863 & 2.280442 & 50.30406 & 2.200000 \\
\hline Standard Deviation & 0.371738 & 2.423642 & 0.609527 & 1.978032 & 0.260957 & 9.156083 & 0.815673 \\
\hline Skewness & 0.090341 & -0.020889 & 0.400307 & -0.919966 & 0.116103 & 0.178081 & -0.119019 \\
\hline Kurtosis & 1.554802 & 1.818076 & 2.059295 & 2.778537 & 1.656505 & 1.900567 & 1.781195 \\
\hline Jarque-Bera Provability & 2.298015 & 1.515248 & 1.653069 & 3.720593 & 2.013807 & 1.446906 & 1.670659 \\
& 0.316951 & 0.468779 & 0.437563 & 0.155626 & 0.365349 & 0.485074 & 0.433732 \\
\hline Sum. & 436.9435 & 928.9780 & 651.6169 & 387.5373 & 69.12638 & 1680.577 & 91.81600 \\
\hline Sum Sq. Dev & 3.454732 & 146.8510 & 9.288085 & 97.81527 & 1.702462 & 2095.846 & 16.63307 \\
\hline No. of observation & 26 & 26 & 26 & 26 & 26 & 26 & 26 \\
\hline
\end{tabular}

Note: WR - Wage Rate; LNIPC - Log of Income Per Capita; LNGDP - Log of Gross Domestic Product; LNFDI - Log of Foreign Direct Investment; AR - Age Rate; and UEMP - Unemployment. 
From the descriptive result (Table 1), which is gotten that the mean value of the employment $\log$ form is 16. 80552. The mean values for wage rate, income per capita in log form, gross domestic product in log form, foreign direct investment in log form, age rate, and unemployment are 35.72992, 25.06219, 14.90 $528,2.658707,64.63759$, and 3.531385 respectively. That is a sample mean values in this table. The total number of observations is 26 . This table also presentations the result of maximum, minimum values. Each value of standard deviation is a measure of the dispersion or scatter of the data. From the above result of Skewness and Kurtosis, the Jarque and Bera (JB) test can be easily counted. Therefore, the result concludes the values of dependent and exogenous variables in a descriptive manner.

\section{Ordinary Least Square Result (OLS)}

The Ordinary Least Square (OLS) of the specified data is indicated in the following form:

$$
\begin{gathered}
L N E M P=16.53767+.0001093 W R-.0534655 L N I P C+.0016071 L N G D P+.9899923 L N F D I-.0163277 A R \\
+.000918 U E M P
\end{gathered}
$$

\begin{tabular}{|c|c|c|c|c|c|c|}
\hline Variables & Coefficient & Std. error & t-ratio & Prov> F & $R 2$ value & $F$ Statistics \\
\hline $\mathrm{C}$ & 16.53767 & .1588725 & 104.09 & \multirow{7}{*}{0.0000} & \multirow{7}{*}{1.0000} & \multirow{7}{*}{$\begin{array}{l}65187.42 \\
(6,19)\end{array}$} \\
\hline WR & .0001093 & .0010612 & 0.10 & & & \\
\hline LNIPC & -.0534655 & .0053863 & -9.93 & & & \\
\hline LNGDP & .0016071 & .0007804 & 2.06 & & & \\
\hline LNFDI & .9899923 & .0062575 & 158.21 & & & \\
\hline AR & -.0163277 & .0004704 & -34.71 & & & \\
\hline UNEMP & .000918 & .0020845 & 0.44 & & & \\
\hline
\end{tabular}

Table 2: Taking Ordinary Least Squares (OLS), LNEMP as Dependent variable (1992-2017)

From the regression model gotten above (Table 2), holding all other factors constant the total employment is 16.53767 , which is positive. The result shows that the wage rate is .0001093 , the income per capita is -.0534655 that decreases in LNEMP. The GDP is .0016071 , the foreign direct investment inflow is .9899923 , and the unemployment rate is .000918 meaning that goes up positive on usual holding another variable constant by LNEMP.

The age rate is -.0163277 suggesting that it goes down unusual holding another variable constant by LNEMP. We know that $R^{2}$ is a non-decreasing purpose of the number of descriptive variables. The value of $R^{2}$ (coefficient of determination) is 1.0000 in the model represents that $100 \%$ of the deviation in the dependent variable (LNEMP) is due to exogenous variables included in which authenticates the model.

Here, $R^{2}$ explains that there is a durable and linear relationship with the goodness of fit between the multivariable regression of dependent and exogenous variables. Then, all $t$ values like that are significant at
5 percent level. The $\mathrm{F}$ value test is also statistically extremely significant at 1 percent, which suggests that the null proposition is rejected. The result also designates that the wage rate, income per capita, the gross domestic product, the foreign direct investment inflow, age rate, and unemployment rate directly affect employment. The income per capita and age rate have not a positive effect on labor demand in Bangladesh.

From the above outcome, the residuals from the linear regression (1) appear to be not asymmetrically distributed. Application of the Jerque-Bera test indications that the JB statistic is about 0.405899 and the probability of finding such a statistic under the normality assumption is about 81 percent. This probability is moderately high. These probabilities were attained from a sample of 26 observations, which seems reasonably high. Therefore, we do not reject the null hypothesis at $1 \%, 5 \%$, and $10 \%$ level of insignificance that the residuals term is normally distributed (Basak et al., 2006). 


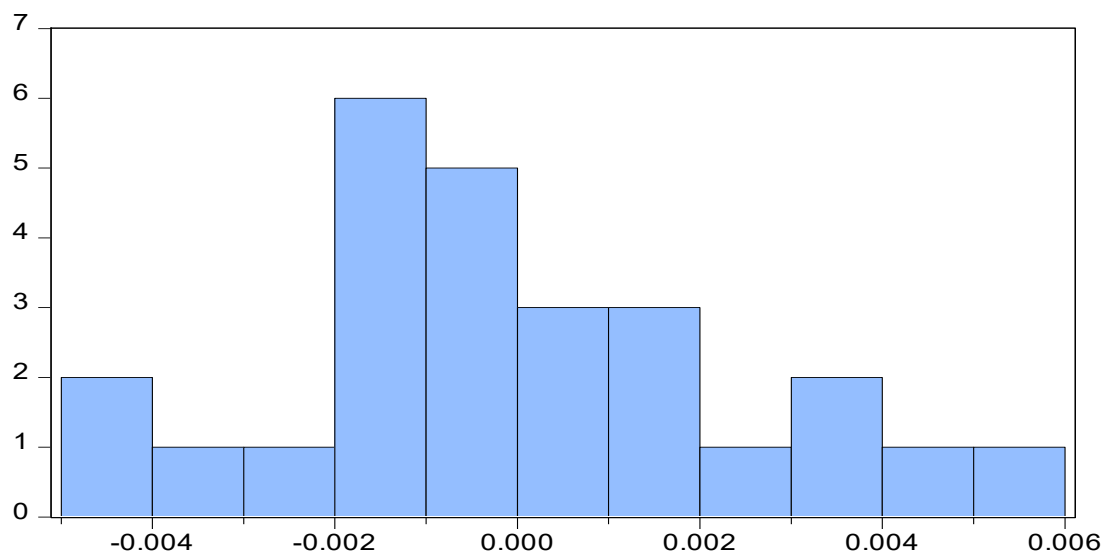

\begin{tabular}{ll}
\hline \multicolumn{2}{l}{ Series: Residuals } \\
Sample 1992 2017 \\
Observations 26 \\
Mean & $-2.50 e-15$ \\
Median & -0.000177 \\
Maximum & 0.005391 \\
Minimum & -0.004726 \\
Std. Dev. & 0.002591 \\
Skewness & 0.223117 \\
Kurtosis & 2.581013 \\
& \\
Jarque-Bera & 0.405899 \\
Probability & 0.816320 \\
\hline
\end{tabular}

Fig 1: Graph of Jerque-Bera Test of Normality (The test is designed by E-views student $10^{+}$lite version).

Table 3: Descriptive test of Log of Total Export, Exchange Rates, Employment in industry Rate, and Trade Balance.

\begin{tabular}{|c|c|c|c|c|}
\hline & LNEXP & EXR & EMPIR & TB \\
\hline Mean & 9.136066 & 60.00615 & 14.75419 & -5.736923 \\
\hline Median & 9.001067 & 60.16500 & 14.27650 & -3.860000 \\
\hline Maximum & 10.45322 & 79.93000 & 21.06500 & -1.520000 \\
\hline Minimum & 7.597858 & 38.15000 & 9.781000 & -17.66000 \\
\hline Standard Deviation & 0.885045 & 14.76412 & 3.869990 & 4.241306 \\
\hline Skewness & 0.008901 & -0.125179 & 0.358840 & -1.062919 \\
\hline Kurtosis & 1.834721 & 1.581433 & 1.752697 & 3.363826 \\
\hline Jarque-Bera Provability & $\begin{array}{l}1.471374 \\
0.479176\end{array}$ & $\begin{array}{l}2.247928 \\
0.324989\end{array}$ & $\begin{array}{l}2.243400 \\
0.325726\end{array}$ & $\begin{array}{l}5.039190 \\
0.080492\end{array}$ \\
\hline Sum. & 237.5377 & 1560.160 & 383.6090 & -149.1600 \\
\hline Sum Sq. Dev & 19.58262 & 5449.481 & 374.4206 & 449.7170 \\
\hline No. of observation & 26 & 26 & 26 & 26 \\
\hline
\end{tabular}

\section{Ordinary Least Square Result (OLS)}

The Ordinary Least Square (OLS) of the specified data is indicated in the following form:

$$
L N E X P=6.2849+.0526026 E X R-.0489941 E M P I R-.072784 T B
$$

Table 4: Taking Ordinary Least Squares (OLS), LNEXP as Dependent variable (1992-2017)

\begin{tabular}{|c|c|l|c|c|c|c|}
\hline Variables & Coefficient & Std. error & t-ratio & Prov $>$ F & R2 value & F statistics \\
\hline C & 6.2849 & .2042767 & 30.77 & & \\
EXR & .0526026 & .0058027 & 9.07 & \multirow{2}{*}{0.0000} & 0.9736 & 270.46 \\
EMPIR & -.0489941 & .0278769 & -1.76 & & $(3,22)$ \\
\hline TB & -.072784 & .0175476 & -4.15 & & \\
\hline \multicolumn{7}{|l}{ Source: (The test is showed by using Stata/SE 15.0 and see the appendices) } \\
\hline
\end{tabular}

From the regression model gotten above (Table 4) that, holding all other factors constant the total employment is 6.2849 , which is positive. The result shows that the exchange rates are .05260 , employment of industry rates is -.0489941, and trade balance is .072784 that decreases in LNEXP. We know that
$R^{2}$ is a non-decreasing purpose of the number of descriptive variables. The value of $R^{2}$ (coefficient of determination) is 0.9736 in the model represents that 97\% of the deviation in the dependent variable (LNEXP) is due to exogenous variables included in which authenticates the model. 
Here, the value of $R^{2}$ explains that there is a positive and linear relationship with the goodness of fit between the multivariable regression of dependent and exogenous variables. Then, all $t$ values like that are significant at 5 percent level. The $\mathrm{F}$ test value is also statistically particularly substantial at 1 percent, which suggests that the null proposition is rejected.

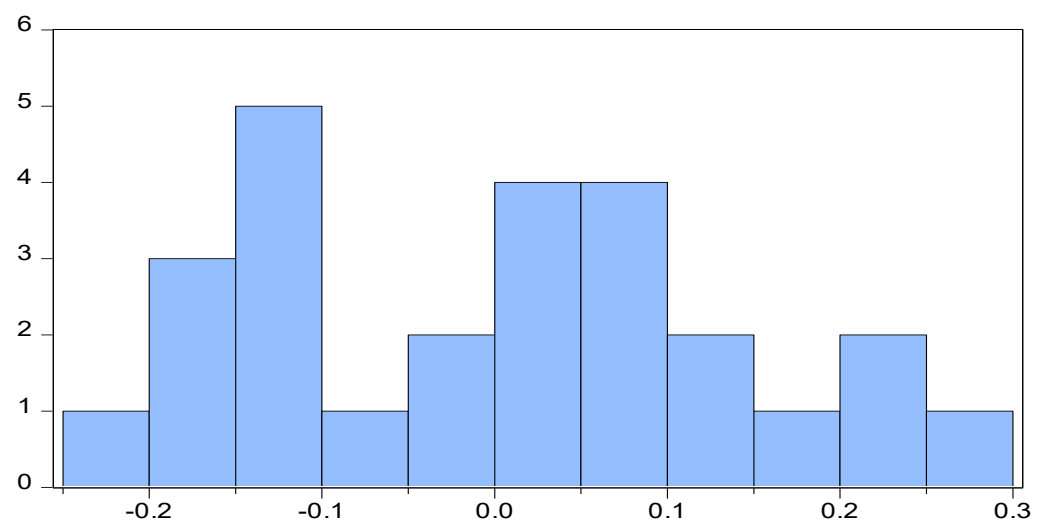

The result also designates that exchange rates, employment of industry rates, and trade balance directly affect the employment (Saha et al., 2020). The employment of industry rates and trade balance has not a positive effect on export-oriented industrialization in Bangladesh (Stephenson and Hoffbauer, 2010; WTS, 2016).

Fig 2: Graph of Jarque-Bera Test of Normality (The test is designed by E-views student $10^{+}$liteversion)

From the above outcome, the residuals from the linear regression (1) appear to be not asymmetrically distributed. Application of the Jerque-Bera test indications that the JB statistic is about 0.974366 and the probability of finding such a statistic under the normality assumption is about 61 percent. This probability is moderately high. These probabilities were attained from a sample of 26 observations, which seems reasonably severe. Therefore, we do not discard the null proposition at $1 \%, 5 \%$, and $10 \%$ level of insignificance that the residuals term is usually distributed.

\section{DISCUSSION:}

The findings disclose that the Ordinary Least Square (OLS) methods confirms that the positive correlation regression analysis and is a non-decreasing purpose of the number of descriptive variables. The value of (coefficient of determination) in the model represents that $100 \%$ of the deviation in the dependent variable is due to exogenous variables included in which authenticates in these models. Therefore, the value of explains that here is a durable and linear relationship with the goodness of fit between the multivariable regression of dependent and exogenous variables.

To test the normality of the disturbance terms JerqueBera (JB) normality test is accepted. The Jerque-Bera (JB) normality test approves that the disturbance terms are normally distributed. The Unit Root Test has been detected to test the stationarity of the collected data. The Johansen co-integration test adopts to test whether the data are cointegrated at any level in these models. The VECM method observes to the short-run and long-run relationship of the independent variables together with dependent variable.

And the Granger Causality test under VAR (Vector Autoregressive Regression) framework demonstrations the variable has a unidirectional causal relationship with dependent variable where all independent variables follows. On the base of findings of the research study, it may be resolved that earnings from labor demand and export-oriented industrialization show positive growth per annum during the whole study period (Yamagata, 2006). It is also concluded that instability in exports of the readymade garments, exchange rates, and economic growth rates enlarged in the recent past (Zohir, 2001; Nahid et al., 2019). Well labor demand industrialized and systematic export promotion program is needed for exports which will have a significant impact on both industrial and economic development (Afaf et al., 2015).

\section{CONCLUSION:}

Thus, the growing rate in labor demand and exportoriented industrialization of Bangladesh for future years will be satisfactory. These experimental findings can be significant source of evidence for the 
manufacturers, traders, laborers, exporters, policy makers and researchers to build basis for further research in this sector. This investigation focused on the current situation; to investigate econometrically of many exogenous variables, to evaluate the impact of export-oriented industrialization, to observe the average of existing of labor constructed on their wage, classify the problems, resolutions and, comm.endations founded on the study, and effect on economic position of labor demand and exportoriented industrialization in Bangladesh (YAO and YU, 2009). The analysis of the petition for labor showing that engaged with labor was one-third of all labor and its export percentage grew up which have solely passed the low-cost of Bangladesh until now. Moreover, the government should maintain an export friendly environment to sustain economic growing in the future. On the foundation of findings of the research study, it may be resolved that earnings from labor demand and export-oriented industrialization show positive growth per annum during the whole study period. These experimental findings can be significant source of evidence for the manufacturers, traders, labourers, exporters, and researchers to build basis for further research in this sector.

\section{REFERENCES:}

1. Adnan T, (2018). "Low Wage Crisis: Impacts on Bangladeshi Garment Sector Workers", Adnan, J. Mass Communicate Journalism, 8:1 https://doi.org/10.4172/2165-7912.1000357

2. Afaf Abdull J. Saaed and Majeed Ali Hussain, (2015). "Impact of Exports and Imports on Economic Growth: Evidence from Tunisia", Journal of Emerging Trends in Economics and Management Sciences, 6(1):13-21.

3. Ahmad and Khan, (2007)" Employment and unemployment situation in Bangladesh: a dismal picture of development'. Pp. 1-29. https://bea-bd.org/site/images/pdf/010.pdf

4. Anda David and Mohamed Ali Marouani, (2013). "The Impact of Labor Mobility on Unemployment: A Comparison Between Jordan And Tunisia',. Pp. 1-30. http://conference.iza.org/conference_files/world b2013/david a9169.pdf

5. Bangladesh Garment Manufacturer and Exporters Association (BGMEA), (2013). http://www.bgmea.com.bd/home/pages/tradeinfo rmation\#.VfJdwC637os

\section{ACKNOWLEDGEMENTS:}

All praises are due to the omnipotent, omnipresent and merciful Allah, who permitted the author to explore her higher studies to complete the research work along the way. In my pathway towards this research work I have found a teacher, an inspiration, a pillar of assistance in my guide, and supervisor, Binata Rani Sen, Assistant Professor, Department of Economics, Noakhali Science and Technology University, Noakhali. Foremost, I would like to prompt my sincere embraced gratitude and a deep sense of respect to my supervisor for her the continuous support of my research study and for her patience, unconditional love, guidance, advice, enthusiasm, inspiration and immense knowledge. I could not have imagined having a better supervisor and mentor for my master's thesis study.

\section{CONFLICT OF INTERESTS:}

The researcher declares no possible conflict of interest concerning the study, data collection and analysis, authorship and publication of this present article.

6. Basak, I., Basak, P., \& Balakrishnan, N. (2006). On some predictors of times to failure of censored items in progressively censored samples. Computational Statistics \& Data Analysis, 50(5), 1313-1337.

https://doi.org/10.1016/j.csda.2005.01.011

7. Getahum , (2018). "Labour-Intensive Jobs for Women and Development: Intra-household Welfare Effects and Its Transmission Channels," 54(7): 1232-1252. https://doi.org/10.1080/00220388.2017.1327661

8. Islam Md. Khairul and Hossain Md. Elias, (2014). Human Capital, Export and Economic Growth in Bangladesh: A Time Series Analysis, J. Soc. Bus. Stu, RU, Pp. 1-12. https://www.researchgate.net/publication/320805 $\underline{680}$

9. Jajri, I. and Ismail, R. (2010). Impact of labor quality on labor productivity and economic growth. African Journal o-f Business Management. 4(4), 486-495.

10. Khan AN, and Ullah MR. (2017)" Export Scenario between Bangladesh and China: 
Opportunities of Bangladesh in RMG Sector" 13(28): Pp. 299.

https://doi.org/10.19044/esj.2017.v13n28p299

11. Khan, S. I. (2001). "Gender Issues and the Ready Garment Industry of Bangladesh: The trade Union Context." In R Sobhan and N Khundker (eds.) Globalization and Gender: Changing Patterns of Women's Employment in Bangladesh. Dhaka: University Press Ltd.

12. Krainara, (2007). "Export-Oriented Industrialization (EOI): Arguments for and Against What Have Been Experienced of Developing Countries about EOI", Pp. 1-23.

https://www.researchgate.net/publication/262196 $\underline{840}$

13. Michael Spence A. (2017). The Global Economy in 2018. Retrieved from -

https://www.cfr.org/article/global-economy$\underline{2018}$

14. Mitchell W. (2008). "Labour Mobility and Low-paid Workers", Centre of Full Employment and Equity, December 2008.

15. Nahid SAA, Jahan MS, Jahan AA, Alam MS, and Roy RC. (2019). Assessment, monitoring, and awareness of garment workers regarding the prevalence of tuberculosis in Savar, Dhaka. Eur. J. Med. Health Sci., 1(5), 30-40. https://doi.org/10.34104/ejmhs.0193040

16. Rasiah and Nazeer, (2016). "Comparing Industrialization in Pakistan and the East Asian Economies," The Lahore Journal of Economics, 21: Pp. 167-192. https://doi.org/10.35536/lje.2016.v21.isp.a7

17. Saha S, Sarker R, and Ahmed SM. (2020). Impact of Green Human Resource Management (GHRM) practices in garment industry: Bangladesh perspective, Int. J. Manag. Account. 2(2), 22-30. https://doi.org/10.34104/ijma.020.022030
18. Stephenson, S. and G. Hoffbauer, (2010). "International Trade in Services: New Trends and Opportunities for Developing Countries, World Bank Publications,"

19. Tran A. N. and Norlund I. (2015). "Globalization, industrialization, and labor markets in Vietnam," 20(1), 143-163. https://doi.org/10.1080/13547860.2014.974343

20. Van, (2009). "Dutch Disease in the Labor Market: Women, Services, and Industrialization," Review of Development Economics, 13(4), 560-575. https://doi.org/10.1111/j.1467-9361.2008. 0049 $\underline{4 . x}$

21. WDI, (2020). World Development Indicators, Retrieved from -

https://datacatalog.worldbank.org/dataset/worlddevelopment-indicators

22. WTS, (2016). World Trade Statistics, Retrieved from -

https://globaltradefunding.com/knowledgebase/research-library/world-trade-statisticalreview-2016/

23. Yamagata, (2006). "The Garment Industry in Cambodia: It's Role in Poverty Reduction through Export-Oriented Development" Discussion Paper No. 62. Pp. 1-49.

https://www.ide.go.jp/English/Publish/Downloa d/Dp/062.html

24. YAO Y., and YU M. (2009). "Labour, Demography, and the Export-oriented Growth Model in China," The Journal of Comparative Economic Studies, 5, pp.61-78. https://ideas.repec.org/a/cos/epaper/v5y2009p6178.html

25. Zohir, S.C. (2001). "Social Impact of Growth of Garments Industry in Bangladesh" The Bangladesh Development Studies, 27(4), pp. 41-80.

Citation: Sultana T. (2020). Labor demand and export-oriented industrialization of Bangladesh, Asian J. Soc. Sci. Leg. Stud., 2(6), 115-121. https://doi.org/10.34104/ajssls.020.01150121 (c) 